American Journal of Economics and Business Administration 3 (2): 293-300, 2011

ISSN 1945-5488

(C) 2011 Science Publications

\title{
The Empirical Study of Japanese Deposit Withdrawal Behaviors on Unstable Financial Environment
}

\author{
${ }^{1}$ Toshihiko Takemura, ${ }^{2}$ Takashi Kozu and ${ }^{3}$ Tetsuro Kobayashi \\ ${ }^{1}$ The Research Institute for Socionetwork Strategies, Kansai University, \\ 3-3-35, Yamate-Cho, Suita, Osaka, 564-8680, Japan \\ ${ }^{2}$ Ricoh Institute of Sustainability and Business, \\ ${ }^{2}$ Marunouchi Kitaguchi Building 20F, 1-6-5 Marunouchi, Chiyoda-ku, \\ Tokyo, 100-0005, Japan \\ ${ }^{3}$ National Institute of Informatics, 2-1-2 Hitotsubashi, Chiyoda-Ku, \\ Tokyo, 101-8430, Japan
}

\begin{abstract}
Problem statement: We need to analyze to withdrawal behavior rather than deposit behavior on the situation which financial institutions might fail. However, there are few studies on withdrawal behavior although there are various studies on individual deposit behavior. Approach: Our purpose of this study is to investigate relationships between individual's deposit withdrawal behavior and economic and psychological factors using micro data from an Internet (Web-based) survey. Results: We confirm that individual's withdrawal behavior is strongly affected by not only economic factors, but also psychological factors. In many cases, sign of estimated coefficient of economic factors are consistent with theory of economic behavior. In addition, effects of psychological factors such as degree of trust in information sources and degree of risk aversion are not uniformly against individual's deposit-withdrawal behavior. Furthermore, we confirm that the probability that they carelessly withdraw their deposits tends to be lower if individuals correctly understand Japanese deposit insurance scheme. Conclusion: For reducing the ratio of individuals who do not correctly understand the Japanese deposit insurance scheme, we propose that the government should announce and educate the scheme to people strongly.
\end{abstract}

Key words: Withdrawal behavior, empirical study, stepwise logistic regression method, web-based survey, Japanese deposit insurance scheme

\section{INTRODUCTION}

We have various studies on individual behavior on depositing their money in economics. However, there are few studies on withdrawal behavior. The reason is simple. Because deposit is safe asset, from perspective of economic rationality, we did not need to analyze deposit-withdrawal behavior excluding purpose of consuming. In field of economics, it is assumed that individuals did not have incentive to withdraw their deposits. On the other hand, we need to analyze to withdrawal behavior rather than deposit behavior on the situation which financial institutions might fail. We have hypothesis that withdrawal behavior is strongly affected by not only economic factors, but also psychological factors. Therefore, we quantitatively analyze withdrawal behavior based on micro economic model with psychological factors. Concretely, we use micro data from our Web-based survey and microeconometric method. This result implies to supply some materials on avoiding financial panic such as a bank run and we obtain a cue to understand mechanisms of the situation. Takemura and Kozu (2009) point out that analyses based on micro data would be more superior rather than ones based on aggregated data in the studies on financial behavior. Up to now, it is not paid attention to individual's withdrawal behavior because we have no usable micro data, or because it is not necessary to analyze it. However, it has come to attract attention with the failure of the subprime loan problem and Lehman Brothers that happened in 2007. There are many qualitative studies on bank run (Allen and Gale, 2007; Shiller, 2008). On the other hand, quantitative or empirical studies are novel and the accumulation of

Corresponding Author: Toshihiko Takemura, The Research Institute for Socionetwork Strategies, Kansai University, 3-3-35, Yamate-Cho, Suita, Osaka, 564-8680, Japan 
such studies is considerably few. Briefly, here we introduce some empirical studies using micro data; Takemura and Kozu (2009) and Yada et al. (2009).

Takemura and Kozu (2009) statistically analyze individuals' deposit withdrawal behaviors in Japan using micro data from a Web-based survey they conducted and clarify some factors influencing their behaviors. Then, they suggest that banks and authorities have to pay attention to information sources that individuals frequently use and if the chain of uneasiness could be blocked with such knowledge, it might be possible to avoid unnecessarily panics. Besides, they confirm that there are no statistical relationships between individuals' deposit withdrawal behavior and economic variables such as annual income and amount of deposit. Yada et al. (2009) analyze individual's deposit withdrawal behavior using micro data and data mining technique. Then, they clarify some factors that influence the individual behavior. In addition, they estimate the total amount of deposit in each branch of a financial institution that should be prepared when a bank run occurs.

\section{MATERIALS AND METHODS}

Model and statistical method: Takemura and Kozu (2009) modeled individuals' deposit withdrawal behaviors when they receive information with regard to financial turmoil such that probability of failure of financial institution is $\mathrm{k} \%$ and analyze this information using a stepwise binary logistic regression method.

Similarly, we build a model by a binary logistic regression equation, in which the explained variable is the probability that individual withdraws his deposits after receiving information on financial turmoil. Explanatory variables are grouped roughly as follows: (1) degree of trust in information sources, $X_{T}$, (2) the number of friends or colleagues with whom individuals exchange information, $X_{E}$, (3) individual transactions with banks, $X_{R}$ and (4) individual attributes, $X_{A}$.

If we can set the probability of failure of the bank which individual uses mainly, $\mathrm{k}$ (\%), the relationship between the explained variable and the explanatory variables is simply described as Eq. 1:

$\log \left(p_{k} /\left(1-p_{k}\right)\right)=b_{T} X_{T}+b_{E} X_{E}+b_{R} X_{R}+b_{A} X_{A}$

where, $p_{k}$ is the probability that the individual withdraws his deposit after receiving information on the probability of failure of his bank, $k(\%)$ and $b_{j}(j=T, F$, $R$ and $A$ ) represent a logarithm odds of variable $X_{j}$. This can be interpreted as the degree to which individuals are apt to withdraw their deposits.

For example, if $\mathrm{X}_{\mathrm{j}}$ with the ordinary property changes one unit and the coefficient $b_{j}$ is positive (resp. negative), then individual is apt to (resp. not to) withdraw all of his deposit after receiving information on the probability of failure of his bank. On the other hand, if a coefficient of a variable is zero, the factor does not affect individual's deposit withdrawal behavior. A bank run will occur if a certain numbers of individuals withdraw their deposits and such a situation is an undesirable one for banks. Therefore, it is important to recognize the meaning of variables in Eq. 1 to understand the mechanism of bank run. Our model expressed by Eq. 1 incorporates psychological variables in addition to economic ones in the decision-making of depositors. It is assumed that depositor would be strongly affected by psychological factors if they face on a bank run. As psychological factors, we use degree of risk aversion, time discount rate and degree of trust in information sources and the frequency of accessing the sources.

Let us briefly, we explain the methods and the processes to estimate the coefficient in Eq. 1 and to evaluate the fit of our model. First of all, all variables concerned with deposit-withdrawal behavior collected from the survey are incorporated into Eq. 1 by using a stepwise binary logistic regression method. Any stepwise procedure for selection or deletion of variables from a model is based on a statistical algorithm that checks for the importance of variables and either includes or excludes them on the basis of a fixed decision rule. Employing a stepwise selection procedure can provide a fast and effective means to screen a large number of variables and to fit a number of logistic regression equations simultaneously. In this study, especially, we use backward selection procedure. Backward selection is to fit the full model on all explanatory variables at first step and remove the leastsignificant term and re-estimate while it is insignificant. Then, it is evaluated that the fitness and the validity of the model in Eq. 1 by using a positive distinction rate.

Data set: We use data from an Internet (Web-based) survey. Web-based survey is gaining attention as a new approach in the field of marketing research. As you know, a Web-based survey has some statistical problems on sampling. It is not necessarily undesirable to use a Web-based survey if the aim of the survey is to offer judgmental materials that are useful for individual and organizational decision makings. Of course, we must discuss the accuracy of the survey, but unfortunately we cannot make comparison as there is no similar survey other than the Web-based surveys. In near future, we will need to expand the scope of the utilization of the data from a Web-based survey. 
We use data from a Web-based survey conducted in February, 2010 (URL: http://www.kansai-u.ac.jp/ riss /en/shareduse/database.html). The subjects of this survey are Japanese depositors who have more than one bank account, are more than 20 years old. Because bias of respondents occurs by day and time zone that survey is conducted, samples of this survey are arranged according to three dimensions; gender, age and living area in Japan. To arrange three dimensions, we use the data on the number of population by age group and prefecture divisions in "the number of population and household movements based on basic resident registration on the 31st, March, 2008”.

The aim of this survey is to capture individual deposit withdrawal behavior from the viewpoints of economics and psychology. This survey asks more than 50 question items such as gender, annual income, degree of risk aversion, the number of friends and so on. This survey includes 9,411 respondents.

Individuals' deposit withdrawal behavior: The event for the explained variable in Eq. 1 is whether or not an individual withdraw his entire deposit after receiving information on the probability of failure of his bank, $\mathrm{k} \%$. Other behaviors such as withdrawal of a part of the deposit are not considered in this study. Thus, the explained variable in Eq. 1 is defined as follow:

$\mathrm{p}_{\mathrm{k}}=1$ if he withdraws his deposit 0 otherwise

where, $p_{k}$ represents the probability that individual withdraws his/her deposit after receiving information on the probability of failure of his bank, $\mathrm{k}(\%)$.

In this survey, it is asked questions on deposit withdrawal behavior given ten kinds of different probabilities of failure of the depositor's bank; $\mathrm{k}=0.1$, $0.5,1,2,5,10,20,30,50$ and 99. Figure 1 shows distributions for deposit withdrawal behavior.

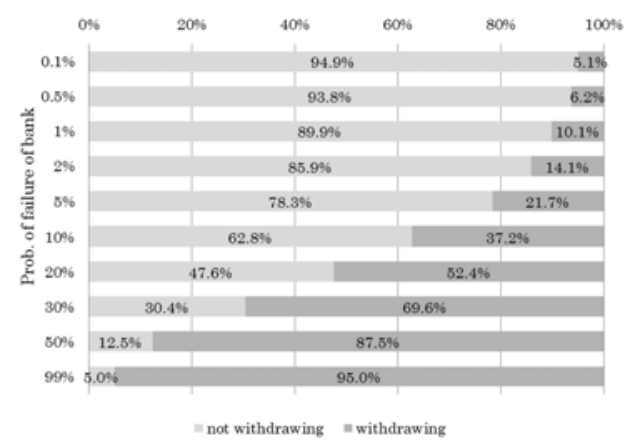

Fig. 1: Distribution for deposit withdrawal behavior
When probability of failure of depositor's bank is $10 \%$, almost half of the numbers of individuals intend to withdraw their deposits. It seems that a relation between probability of failure and the ratio of individuals withdrawing deposits show the $\mathrm{S}$ curve. Then, as a feature, $5 \%$ of respondents withdraw their deposits even if the probability is (0.1-5) \% of respondents do not withdraw their deposits even if the probability is 99\%. In the former case, many of respondents answer that they would withdraw their deposits if there is a little probability of failure $(k>0)$. On the other hand, in the latter case, some of respondents answer that they would never withdraw their deposits because the deposits are guaranteed by the Japanese deposit insurance scheme. The overall tendency is similar to Takemura and Kozu (2009).

Degree of trust in information sources and frequency of accessing the sources: In Takemura and Kozu (2009), we find that some degrees of trust in information sources influence individual's deposit withdrawal behavior. In this survey, it is asked questions about the degree of trust in information sources for bad news. We use 11 kinds of information sources; (1) TV news program, (2) TV wide show program, (3) Newspaper, (4) the Internet excluding 2channel, (5) 2-channel, (6) conversation with neighbors, (7) conversation with people at workplace, (8) E-mail or phone call with friends, (9) radio program, (10) Weekly/monthly magazines and (11) conversation of strangers. Degree of trust in information sources, $\mathrm{X}_{\mathrm{T1-i}}$ and frequency of accessing the sources, $\mathrm{X}_{\mathrm{T2}-\mathrm{i}}$, are assigned between 1 and 5 (1: I never trust it, 2: I do not trust it at all, 3: I am indifferent of trusting it, 4: I weakly trust it, 5: I strongly trust it). Distributions for the degree of trust in information sources and frequency of accessing the sources are shown in Fig. 2.

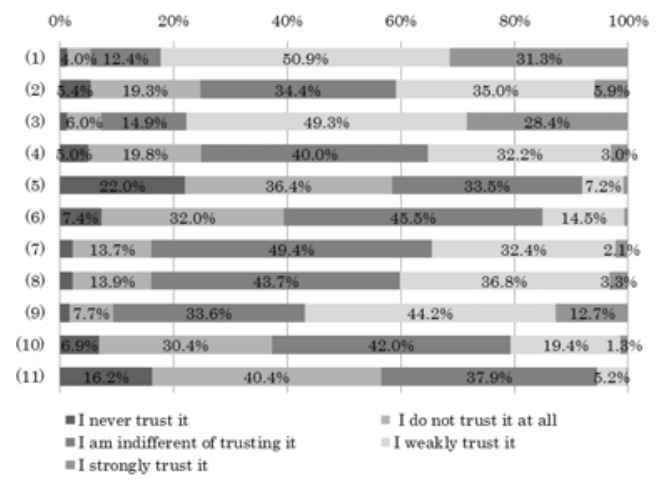

Fig. 2: Degree of trust in information source 
Am. J. of Economics and Business Administration 3 (2): 293-300, 2011

It can be checked that the degree of trust in information sources and frequency of accessing the sources are different in each source. From Fig. 2, we can see many individuals who trust in TV news program and news Study and they frequently access to the sources.

Degree of Friends or Colleagues Exchanging Information: At the past, Japan had experiments that bank runs occurred by the rumor among persons although their management was healthy (Toyokawa Shinkin in 1973 and Saga bank in 2003). Some cases of bank runs in Japan. Information spreads through not only mass media such as TV news, but also in closed individual interactions. Therefore, we need to pay attention to closed individual interactions. We use the rumor among persons as one variable. Concretely, we use the rate of friends or colleagues bandying about failure of bank and the rate of friends or colleagues withdrawing their deposit actually. The average (median) number of friends or colleagues is 13.59 (resp. 10) persons. In addition, Fig. 3 shows distributions for the rate of friends or colleagues bandying about bank failure, $X_{\mathrm{E} 1}$ and the rate of friends or colleagues withdrawing their deposit, $\mathrm{X}_{\mathrm{E} 2}$, respectively.

The average (median) rate of friends or colleagues bandying about bank failure, $\mathrm{X}_{\mathrm{E} 1}$ and rate of friends or colleagues withdrawing their deposit, $\mathrm{X}_{\mathrm{E} 2}$, are 0.27 (resp. 0.17) and 0.24 (resp. 0.11), respectively.

Transactions of individuals with banks: To capture the transactions of individuals using banks, four variables are used in this study; the number of bank accounts, $X_{R 1}$, total amount of deposit, $X_{R 2}$, type of main bank, $\mathrm{X}_{\mathrm{R} 3}$ and understanding of the Japanese deposit insurance scheme, $X_{R 4}$.

The number of bank accounts is a substitute variable for individuals who intend to decentralize their deposits and the total amount of deposits is needed to judge whether or not the deposits are protected by the Japanese deposit insurance scheme. Table 1 and Fig. 4 show elementary statistics on the number of bank accounts and distribution for the total amount of deposits, respectively.

The type of bank is defined by using the following indicator function:

$\mathrm{X}_{\mathrm{R} 3}=1$ if individual uses mega bank, 0 otherwise

where Japanese mega banks are Tokyo Mistubishi UFJ bank, Mitsui Sumitomo bank, Mizuho bank, Resona

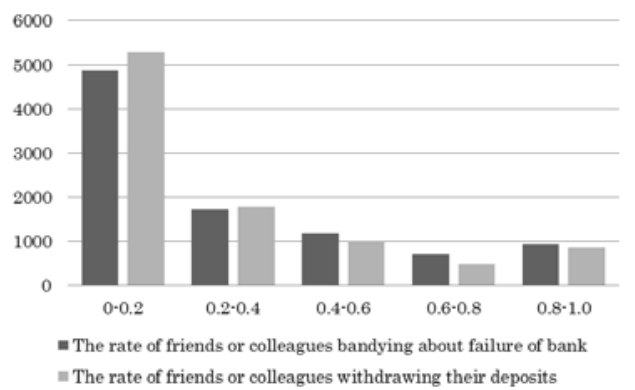

Fig. 3:Distributions for the rate of friends or colleagues bandying about failure of bank and the rate of friends or colleagues withdrawing their deposits

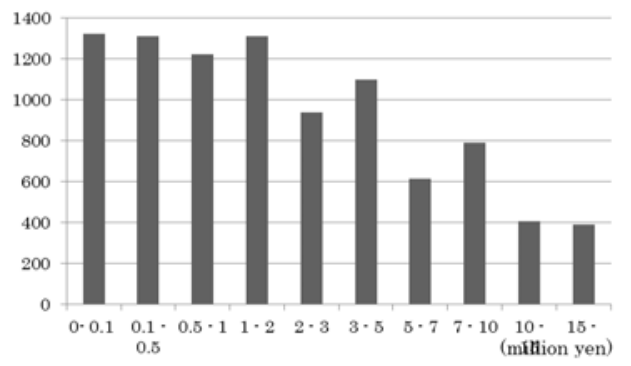

Fig. 4: Distribution for the total amount of deposits

Table 1: Elementary statistics on the number of bank accounts

\begin{tabular}{lllll}
\hline Average & Median & Mode & Skewness & Kurtosis \\
\hline 4.14 & 4 & 3 & 87.914 & 8233.448 \\
\hline
\end{tabular}

bank and Yucho bank. About 54\% of respondents have bank account of mega bank.

Yada et al. (2009) and Takemura and Kozu (2009), they find that understanding of the Japanese deposit insurance scheme influences individuals' deposit withdrawal behaviors. They point out that this variable is an important factor.

In the Japanese deposit insurance scheme, a deposit up to 10 million yen is guaranteed as the upper limit even if the bank fails. According to Fig. 4, it is that the scheme is applied to $92 \%$ of respondents. This result is similar to Takemura and Kozu (2009).

Figure 5 shows distribution for depositors understanding the Japanese deposit insurance scheme.

As the result, $42.3 \%$ of respondents answered that they know the scheme, but do not consider it in their actions. This result has the same tendency with the result of 3rd consumer survey on finance, which the central council for financial services information conducted (URL: http://www.shiruporuto.jp/finance/ chosa/enqu2008/index.html) It is noted that this Study does not regard these answers as understanding the 
scheme and the respondents are included in no understanding in Fig. 5. This result may show that amid heightened anxiety many individuals tend to withdraw their deposits though the deposits are guaranteed by Japanese deposit insurance scheme. In other words, this result implies that system is meaningless if depositors do not correctly understand the system.

In this study, understanding of the Japanese deposit insurance scheme is defined as follows:

$\mathrm{X}_{\mathrm{R} 4}=1$ if depositor understands the scheme 0 otherwise.

Individual attributes: As popular variables for individuals' attributes, the authors use 11 variables in Table 2 as individuals' attributes.

Here, we simply explain time discount rate, degree of risk aversion, expected economic growth rate, degree of trust in government and assessment of current political power.

We believe that these economic-psychological factors are important when individuals make decisions. Therefore, we add some questionnaire in the survey. About time discount rate, according to Ohtake et al. (2010), the time discount rate is assigned between 1 and 5 in this study. In addition, about degree of risk aversion, we adopt behavior on insurance and calculate the degree.

We introduce expected economic growth rate, degree of trust in government and assessment of current political power as psychological factors. We assume that expected economic growth rate represents level of individual future perspective. The others are closely concerned with trust and distrust to political system. Figure 6 and 7 are distribution on expected economic growth rate and degree of trust in government. Table 3 show elementary statistics on assessment of current political power.

From Fig. 7, we can find that many of respondents expect that average economic growth is $0 \%$ or $-1 \%$ and some respondents expect that average economic growth is over $5 \%$. In addition, from Figure 7, it is found that

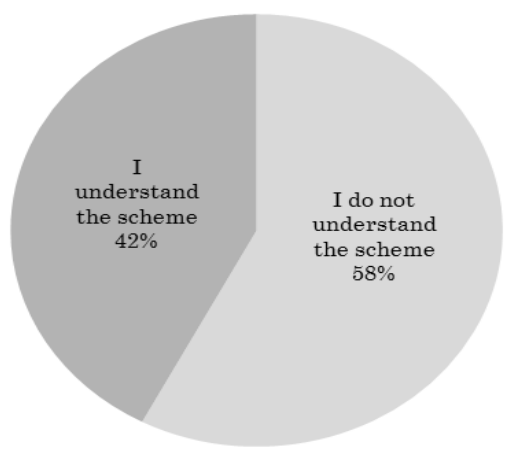

Fig. 5: Distribution for depositors understanding the Japanese deposit insurance scheme

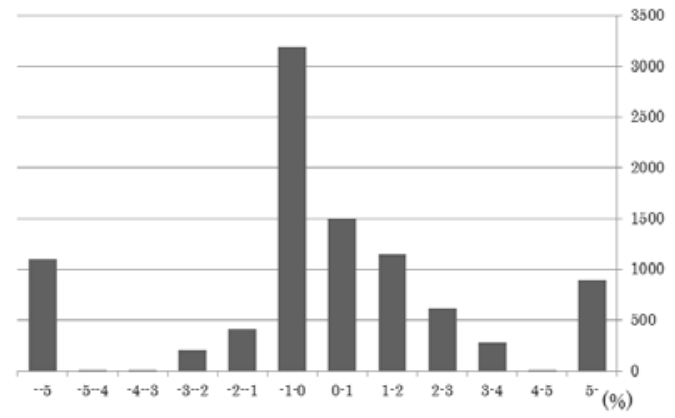

Fig. 6: Expected economic growth rate

Table 2: List of individuals' attributes

\begin{tabular}{|c|c|}
\hline Variable & Content \\
\hline $\mathrm{X}_{\mathrm{A} 1}$ & Gender: 1: Male 2: Female \\
\hline $\mathrm{X}_{\mathrm{A} 2}$ & Age \\
\hline $\mathrm{X}_{\mathrm{A} 3}$ & Marriage status: 0: Unmarried 1: Married \\
\hline $\mathrm{X}_{\mathrm{A} 4}$ & Education: 1: Elementary/ middle school 2: High school 3: Junior college 4: University 5: Master's course 5: Ph.D. \\
\hline \multirow[t]{2}{*}{$\mathrm{X}_{\mathrm{A} 5}$} & Annual income (yen) \\
\hline & $\begin{array}{l}\text { 1: under } 50 \text { thousand 2: } 50 \text { thousand-1 million 3: 1-2 million 4: 2-3 million 5: 3-5 million 6: 5-7 million 7: 7-10 million 8: } 10 \text { - } \\
15 \text { million 9: over } 15 \text { million }\end{array}$ \\
\hline \multirow[t]{2}{*}{$\mathrm{X}_{\mathrm{A} 6}$} & Amount of debt (yen) \\
\hline & $\begin{array}{l}\text { 1: } 0 \text { 2: under } 50 \text { thousand 3: } 50 \text { thousand-1 million 4: 1-2 million 5: 2-3 million 6: 3-5 million 7: 5-million 8: 7-10 million yen } \\
\text { 9: } 10-15 \text { million 10: } 15-30 \text { million 11: over } 30 \text { million }\end{array}$ \\
\hline $\mathrm{X}_{\mathrm{A} 7}$ & $\begin{array}{l}\text { Time discount rate: Compared receiving 10,000 yen now is indifferent with receiving some amount of money after } 1 \text { week } \\
\text { [1: interest } 0 \% \text { 2: interest } 2 \% \text { 3: interest } 6 \% \text { : interest } 10 \% \text { 5: interest } 20 \% \text { ] }\end{array}$ \\
\hline $\mathrm{X}_{\mathrm{A} 8}$ & Degree of risk aversion: Behavior on insurance to theft of 100,000 yen \\
\hline $\mathrm{X}_{\mathrm{A} 9}$ & Expected economic growth rate: Expected economic growth rate in the future 10 years \\
\hline \multirow[t]{2}{*}{$\mathrm{X}_{\mathrm{A} 10}$} & Degree of trust in government: Even if main bank fails, I believe that government grantees my deposit. \\
\hline & [1. I never believe 2: I do not believe 3: I am indifferent of believing 4: I weakly believe 5: I strictly believe] \\
\hline $\mathrm{X}_{\mathrm{A} 11}$ & Assessment of current political power \\
\hline
\end{tabular}


Am. J. of Economics and Business Administration 3 (2): 293-300, 2011

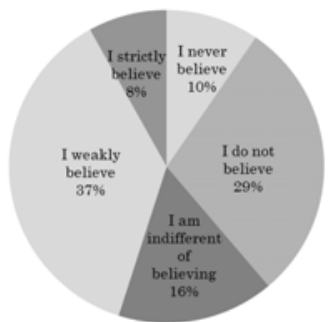

Fig. 7: Degree of trust in government

Table 3: Elementary statistics on assessment of current political power

\begin{tabular}{lllll}
\hline Average & Median & Mode & Skewness & Kurtosis \\
\hline 43.53 & 50 & 50 & -0.153 & -0.569 \\
\hline
\end{tabular}

about $45 \%$ of respondents believe that government grantees deposits, but about $39 \%$ of them do not believe the government.

\section{RESULTS AND DISCUSSION}

Here, we estimate the coefficients in equation (1) by running a stepwise logistic regression method and backward selection procedure. We use ten kinds of different probabilities of failure of bank and 39 explanatory variables. Table 4 and 5 are shown statistics for using tests and the estimated coefficients in Eq. 1, respectively.

From results in Table 4, we evaluate the fit of these models. In each case, Cox-Snell $\mathrm{R}^{2}$ and Nagelkerke $\mathrm{R}^{2}$ are not necessarily high. On the other hand, because the positive distinction rate turns out to be between (59.295) \%, we can insist that these models are valid.

From Table 5, by differences of the probability of failure, variables that finally survive in the backward selection procedure are different.

The estimated coefficients, $b_{R 4}$ and $b_{A 10}$, are statistically significant in all cases. Sign of both the coefficients are negative. The former implies that understanding Japanese deposit insurance scheme decreases the probability of withdrawing their deposits on unstable financial environment.

Similarly, the latter implies that individuals who believe the government tend not to withdraw their deposits. These results indicate that trusting in the government and system is important factor. On the other hand, the estimated coefficients, $b_{\mathrm{T} 1-10}, b_{\mathrm{T} 2-6}, \mathrm{~b}_{\mathrm{R} 3}$ and $b_{A 7}$, are not statistically significant in all cases. For example, these results mean that the difference of bank that individuals deposit and time discount rate that individuals have does not affect withdrawal behavior. Additionally, estimated coefficients, $\mathrm{b}_{\mathrm{T} 1-2}, \mathrm{~b}_{\mathrm{T} 1-4}, \mathrm{~b}_{\mathrm{T} 1-6}$, $b_{\mathrm{T} 1-7}$ and $b_{\mathrm{T} 1-9}$, are not statistically significant in many cases. Then, we can find that individuals who trust in each information source tend to withdraw their deposits.
Table 4: Summary of statistics

\begin{tabular}{lllll}
\hline Case & -2 LL & $\begin{array}{l}\text { Cox- } \\
\text { Snell } \mathrm{R}^{2}\end{array}$ & $\begin{array}{l}\text { Nagelkerke } \\
\mathrm{R}^{2}\end{array}$ & $\begin{array}{l}\text { Positive } \\
\text { distinction } \\
\text { rate }\end{array}$ \\
\hline 1 & 3464.812 & 0.025 & 0.077 & 95.0 \\
2 & 4059.315 & 0.029 & 0.078 & 93.8 \\
3 & 5819.320 & 0.030 & 0.063 & 89.9 \\
4 & 7296.904 & 0.030 & 0.054 & 86.0 \\
5 & 9463.843 & 0.031 & 0.048 & 78.4 \\
6 & 11995.192 & 0.036 & 0.050 & 63.2 \\
7 & 12466.825 & 0.050 & 0.067 & 59.2 \\
8 & 10912.032 & 0.061 & 0.086 & 71.0 \\
9 & 6206.850 & 0.084 & 0.159 & 87.6 \\
10 & 3010.560 & 0.074 & 0.226 & 94.9 \\
\hline
\end{tabular}

Table 5: Estimated Results

\begin{tabular}{|c|c|c|c|c|c|}
\hline \multicolumn{3}{|c|}{ Case 1} & \multicolumn{3}{|c|}{ Case 2} \\
\hline \multicolumn{2}{|c|}{ B } & \multirow{2}{*}{$\begin{array}{l}\text { SE } \\
0.083\end{array}$} & \multicolumn{2}{|r|}{ B } & \multirow{2}{*}{$\begin{array}{l}\text { SE } \\
0.080\end{array}$} \\
\hline$\overline{\mathrm{b}_{\mathrm{T} 1-1}}$ & -0.294 & & $\mathrm{~b}_{\mathrm{T} 1-1}$ & -0.276 & \\
\hline$b_{\mathrm{T} 1-2}$ & 0.208 & 0.069 & $\mathrm{~b}_{\mathrm{T} 1-2}$ & 0.252 & 0.064 \\
\hline $\mathrm{b}_{\mathrm{T} 1-3}$ & -0.147 & 0.075 & $\mathrm{~b}_{\mathrm{T} 1-3}$ & -0.214 & 0.069 \\
\hline $\mathrm{b}_{\mathrm{T} 1-11}$ & 0.208 & 0.062 & $\mathrm{~b}_{\mathrm{T} 1-9}$ & 0.143 & 0.072 \\
\hline $\mathrm{b}_{\mathrm{T} 2-1}$ & -0.101 & 0.051 & $\mathrm{~b}_{\mathrm{T} 1-11}$ & 0.187 & 0.056 \\
\hline $\mathrm{b}_{\mathrm{T} 2-2}$ & 0.156 & 0.039 & $\mathrm{~b}_{\mathrm{T} 2-1}$ & -0.086 & 0.047 \\
\hline $\mathrm{b}_{\mathrm{T} 2-3}$ & -0.062 & 0.034 & $\mathrm{~b}_{\mathrm{T} 2-2}$ & 0.146 & 0.035 \\
\hline $\mathrm{b}_{\mathrm{T} 2-4}$ & -0.130 & 0.033 & $\mathrm{~b}_{\mathrm{T} 2-3}$ & -0.056 & 0.031 \\
\hline $\mathrm{b}_{\mathrm{T} 2-5}$ & 0.081 & 0.047 & $\mathrm{~b}_{\mathrm{T} 2-4}$ & -0.111 & 0.030 \\
\hline $\mathrm{b}_{\mathrm{T} 2-8}$ & 0.077 & 0.039 & $\mathrm{~b}_{\mathrm{T} 2-5}$ & 0.110 & 0.042 \\
\hline $\mathrm{b}_{\mathrm{R} 4}$ & -0.223 & 0.104 & $\mathrm{~b}_{\mathrm{E} 1}$ & -0.265 & 0.146 \\
\hline $\mathrm{b}_{\mathrm{A} 2}$ & 0.025 & 0.004 & $\mathrm{~b}_{\mathrm{R} 4}$ & -0.174 & 0.094 \\
\hline $\mathrm{b}_{\mathrm{A} 4}$ & -0.044 & 0.025 & $b_{\mathrm{A} 2}$ & 0.024 & 0.003 \\
\hline$b_{A 9}$ & -0.001 & 0.001 & $\mathrm{~b}_{\mathrm{A} 5}$ & -0.049 & 0.023 \\
\hline \multirow[t]{2}{*}{$\mathrm{b}_{\mathrm{A} 10}$} & -0.339 & 0.043 & $b_{A 9}$ & -0.001 & 0.001 \\
\hline & & & $\mathrm{b}_{\mathrm{A} 10}$ & -0.329 & 0.039 \\
\hline \multicolumn{2}{|c|}{ Case 3} & & \multicolumn{2}{|c|}{ Case 4} & \\
\hline $\mathrm{b}_{\mathrm{T} 1-1}$ & -0.160 & 0.064 & $\mathrm{~b}_{\mathrm{T} 1-3}$ & -0.094 & 0.036 \\
\hline $\mathrm{b}_{\mathrm{T} 1-2}$ & 0.105 & 0.050 & $\mathrm{~b}_{\mathrm{T} 1-5}$ & 0.077 & 0.036 \\
\hline$b_{\mathrm{T} 1-3}$ & -0.122 & 0.055 & $\mathrm{~b}_{\mathrm{T} 1-8}$ & 0.114 & 0.042 \\
\hline $\mathrm{b}_{\mathrm{T} 1-4}$ & -0.089 & 0.049 & $\mathrm{~b}_{\mathrm{T} 1-11}$ & 0.164 & 0.042 \\
\hline $\mathrm{b}_{\mathrm{T} 1-5}$ & 0.100 & 0.045 & $\mathrm{~b}_{\mathrm{T} 2-1}$ & -0.086 & 0.032 \\
\hline $\mathrm{b}_{\mathrm{T} 1-8}$ & 0.125 & 0.049 & $\mathrm{~b}_{\mathrm{T} 2-2}$ & 0.072 & 0.024 \\
\hline $\mathrm{b}_{\mathrm{T} 1-9}$ & 0.095 & 0.057 & $\mathrm{~b}_{\mathrm{T} 2-3}$ & -0.045 & 0.022 \\
\hline $\mathrm{b}_{\mathrm{T} 1-11}$ & 0.182 & 0.050 & $\mathrm{~b}_{\mathrm{T} 2-4}$ & -0.079 & 0.020 \\
\hline $\mathrm{b}_{\mathrm{T} 2-1}$ & -0.104 & 0.036 & $\mathrm{~b}_{\mathrm{T} 2-7}$ & -0.043 & 0.023 \\
\hline$b_{\mathrm{T} 2-2}$ & 0.096 & 0.028 & $\mathrm{~b}_{\mathrm{T} 2-10}$ & 0.135 & 0.040 \\
\hline $\mathrm{b}_{\mathrm{T} 2-4}$ & -0.068 & 0.024 & $\mathrm{~b}_{\mathrm{E} 1 \mathrm{1}}$ & -0.229 & 0.100 \\
\hline $\mathrm{b}_{\mathrm{T} 2-10}$ & 0.077 & 0.044 & $\mathrm{~b}_{\mathrm{R} 2}$ & 0.026 & 0.013 \\
\hline $\mathrm{b}_{\mathrm{E} 1}$ & -0.254 & 0.116 & $\mathrm{~b}_{\mathrm{R} 4}$ & -0.226 & 0.066 \\
\hline $\mathrm{b}_{\mathrm{R} 4}$ & -0.204 & 0.074 & $\mathrm{~b}_{\mathrm{A} 1}$ & -0.117 & 0.065 \\
\hline $\mathrm{b}_{\mathrm{A} 2}$ & 0.016 & 0.002 & $\mathrm{~b}_{\mathrm{A} 2}$ & 0.013 & 0.002 \\
\hline $\mathrm{b}_{\mathrm{A} 9}$ & -0.002 & 0.001 & $b_{A 9}$ & -0.002 & 0.001 \\
\hline $\mathrm{b}_{\mathrm{A} 10}$ & -0.313 & 0.032 & $\mathrm{~b}_{\mathrm{A} 10}$ & -0.259 & 0.027 \\
\hline $\mathrm{b}_{\mathrm{A} 11}$ & -0.003 & 0.002 & $\mathrm{~b}_{\mathrm{A} 11}$ & -0.002 & 0.001 \\
\hline \multicolumn{3}{|c|}{ Case 5} & \multicolumn{2}{|c|}{ Case 6} & \\
\hline $\mathrm{b}_{\mathrm{T} 1-5}$ & 0.079 & 0.031 & $\mathrm{~b}_{\mathrm{T} 1-5}$ & 0.077 & 0.026 \\
\hline $\mathrm{b}_{\mathrm{T} 1-8}$ & 0.098 & 0.035 & $\mathrm{~b}_{\mathrm{T} 1-6}$ & 0.061 & 0.034 \\
\hline $\mathrm{b}_{\mathrm{T} 1-11}$ & 0.111 & 0.035 & $\mathrm{~b}_{\mathrm{T} 1-8}$ & 0.084 & 0.032 \\
\hline $\mathrm{b}_{\mathrm{T} 2-1}$ & -0.088 & 0.027 & $\mathrm{~b}_{\mathrm{T} 1-9}$ & 0.060 & 0.028 \\
\hline $\mathrm{b}_{\mathrm{T} 2-2}$ & 0.044 & 0.020 & $\mathrm{~b}_{\mathrm{T} 1-11}$ & 0.057 & 0.033 \\
\hline$b_{\mathrm{T} 2-3}$ & -0.042 & 0.018 & $\mathrm{~b}_{\mathrm{T} 2-1}$ & -0.052 & 0.021 \\
\hline $\mathrm{b}_{\mathrm{T} 2-4}$ & -0.062 & 0.017 & $\mathrm{~b}_{\mathrm{T} 2-4}$ & -0.039 & 0.015 \\
\hline $\mathrm{b}_{\mathrm{T} 2-10}$ & 0.114 & 0.034 & $\mathrm{~b}_{\mathrm{T} 2-10}$ & 0.100 & 0.030 \\
\hline $\mathrm{b}_{\mathrm{E} 1}$ & -0.142 & 0.083 & $\mathrm{~b}_{\mathrm{T} 2-11}$ & 0.048 & 0.024 \\
\hline$b_{\mathrm{R} 2}$ & 0.026 & 0.011 & $\mathrm{~b}_{\mathrm{E} 2}$ & -0.132 & 0.073 \\
\hline $\mathrm{b}_{\mathrm{R} 4}$ & -0.272 & 0.055 & $\mathrm{~b}_{\mathrm{R} 2}$ & 0.021 & 0.009 \\
\hline $\mathrm{b}_{\mathrm{A} 1}$ & -0.144 & 0.055 & $\mathrm{~b}_{\mathrm{R} 4}$ & -0.340 & 0.047 \\
\hline $\mathrm{b}_{\mathrm{A} 2}$ & 0.011 & 0.002 & $\mathrm{~b}_{\mathrm{A} 1}$ & -0.199 & 0.048 \\
\hline $\mathrm{b}_{\mathrm{A} 3}$ & -0.134 & 0.060 & $\mathrm{~b}_{\mathrm{A} 2}$ & 0.009 & 0.002 \\
\hline $\mathrm{b}_{\mathrm{A} 4}$ & 0.031 & 0.013 & $\mathrm{~b}_{\mathrm{A} 3}$ & -0.099 & 0.052 \\
\hline $\mathrm{b}_{\mathrm{A} 9}$ & -0.002 & 0.001 & $\mathrm{~b}_{\mathrm{A} 4}$ & 0.021 & 0.011 \\
\hline & -0.236 & 0.023 & $b_{A 6}$ & -0.015 & 0.008 \\
\hline \multirow[t]{4}{*}{$\mathrm{b}_{\mathrm{A} 11}$} & -0.003 & 0.001 & $\mathrm{~b}_{\mathrm{A} 8}$ & -2475.000 & 951.420 \\
\hline & & & $b_{\mathrm{A} 9}$ & 0.000 & 0.000 \\
\hline & & & $\mathrm{b}_{\mathrm{A} 10}$ & -0.214 & 0.020 \\
\hline & & & $\mathrm{b}_{\mathrm{A} 11}$ & -0.002 & 0.001 \\
\hline
\end{tabular}


Am. J. of Economics and Business Administration 3 (2): 293-300, 2011

Table 5: Continue

\begin{tabular}{|c|c|c|c|c|c|}
\hline \multicolumn{2}{|c|}{ Case 7} & \multicolumn{4}{|c|}{ Case 8} \\
\hline \multicolumn{2}{|r|}{$\mathrm{B}$} & SE & \multicolumn{2}{|r|}{ B } & SE \\
\hline $\mathrm{b}_{\mathrm{T} 1-1}$ & 0.090 & 0.028 & $\mathrm{~b}_{\mathrm{T1}-1}$ & 0.106 & 0.031 \\
\hline $\mathrm{b}_{\mathrm{T} 1-5}$ & 0.059 & 0.025 & $\mathrm{~b}_{\mathrm{T} 1-4}$ & 0.055 & 0.029 \\
\hline $\mathrm{b}_{\mathrm{T} 1-6}$ & 0.079 & 0.030 & $\mathrm{~b}_{\mathrm{T} 1-6}$ & 0.062 & 0.037 \\
\hline $\mathrm{b}_{\mathrm{T} 1-8}$ & 0.160 & 0.030 & $\mathrm{~b}_{\mathrm{T} 1-7}$ & 0.106 & 0.038 \\
\hline $\mathrm{b}_{\mathrm{T} 2-1}$ & -0.046 & 0.021 & $\mathrm{~b}_{\mathrm{T} 1-8}$ & 0.176 & 0.036 \\
\hline $\mathrm{b}_{\mathrm{T} 2-4}$ & -0.038 & 0.015 & $\mathrm{~b}_{\mathrm{T} 1-11}$ & -0.060 & 0.035 \\
\hline $\mathrm{b}_{\mathrm{T} 2-10}$ & 0.113 & 0.030 & $\mathrm{~b}_{\mathrm{T} 2-1}$ & -0.053 & 0.024 \\
\hline$b_{\mathrm{T} 2-11}$ & 0.046 & 0.023 & $\mathrm{~b}_{\mathrm{T} 2-4}$ & -0.041 & 0.016 \\
\hline $\mathrm{b}_{\mathrm{R} 1}$ & -0.015 & 0.010 & $\mathrm{~b}_{\mathrm{T} 2-10}$ & 0.128 & 0.033 \\
\hline $\mathrm{b}_{\mathrm{R} 2}$ & 0.041 & 0.009 & $\mathrm{~b}_{\mathrm{T} 2-11}$ & 0.078 & 0.026 \\
\hline $\mathrm{b}_{\mathrm{R} 4}$ & -0.446 & 0.046 & $\mathrm{~b}_{\mathrm{E} 1}$ & 0.133 & 0.075 \\
\hline $\mathrm{b}_{\mathrm{A} 1}$ & -0.310 & 0.046 & $\mathrm{~b}_{\mathrm{R} 1}$ & -0.015 & 0.011 \\
\hline $\mathrm{b}_{\mathrm{A} 2}$ & 0.008 & 0.002 & $\mathrm{~b}_{\mathrm{R} 2}$ & 0.042 & 0.010 \\
\hline $\mathrm{b}_{\mathrm{A} 4}$ & 0.030 & 0.011 & $\mathrm{~b}_{\mathrm{R} 4}$ & -0.629 & 0.050 \\
\hline $\mathrm{b}_{\mathrm{A} 6}$ & -0.013 & 0.007 & $\mathrm{~b}_{\mathrm{A} 1}$ & -0.258 & 0.050 \\
\hline $\mathrm{b}_{\mathrm{A} 8}$ & -2606.000 & 931.170 & $\mathrm{~b}_{\mathrm{A} 2}$ & 0.009 & 0.002 \\
\hline $\mathrm{b}_{\mathrm{A} 9}$ & -0.001 & 0.000 & $\mathrm{~b}_{\mathrm{A} 4}$ & 0.039 & 0.012 \\
\hline \multirow[t]{3}{*}{$\mathrm{b}_{\mathrm{A} 10}$} & -0.231 & 0.019 & $\mathrm{~b}_{\mathrm{A} 8}$ & -3670.000 & 1027.550 \\
\hline & & & $b_{\mathrm{A} 9}$ & -0.001 & 0.000 \\
\hline & & & $\mathrm{b}_{\mathrm{A} 10}$ & -0.252 & 0.021 \\
\hline \multicolumn{2}{|c|}{ Case 9} & \multicolumn{4}{|c|}{ Case 10} \\
\hline $\mathrm{b}_{\mathrm{T} 1-1}$ & 0.170 & 0.052 & $\mathrm{~b}_{\mathrm{T} 1-1}$ & 0.227 & 0.075 \\
\hline $\mathrm{b}_{\mathrm{T} 1-3}$ & 0.107 & 0.049 & $\mathrm{~b}_{\mathrm{T} 1-3}$ & 0.153 & 0.072 \\
\hline $\mathrm{b}_{\mathrm{T} 1-7}$ & 0.188 & 0.052 & $\mathrm{~b}_{\mathrm{T} 1-4}$ & 0.134 & 0.066 \\
\hline $\mathrm{b}_{\mathrm{T} 1-8}$ & 0.199 & 0.049 & $\mathrm{~b}_{\mathrm{T} 1-5}$ & -0.115 & 0.063 \\
\hline$b_{\mathrm{T} 2-1}$ & -0.090 & 0.033 & $\mathrm{~b}_{\mathrm{T} 1-8}$ & 0.306 & 0.066 \\
\hline $\mathrm{b}_{\mathrm{T} 2-10}$ & 0.167 & 0.046 & $\mathrm{~b}_{\mathrm{T} 2-7}$ & 0.076 & 0.035 \\
\hline $\mathrm{b}_{\mathrm{E} 1}$ & 0.898 & 0.119 & $\mathrm{~b}_{\mathrm{T} 2-9}$ & -0.060 & 0.034 \\
\hline $\mathrm{b}_{\mathrm{R} 1}$ & -0.026 & 0.014 & $\mathrm{~b}_{\mathrm{E} 1}$ & 1.573 & 0.350 \\
\hline $\mathrm{b}_{\mathrm{R} 2}$ & 0.061 & 0.015 & $\mathrm{~b}_{\mathrm{E} 2}$ & 0.619 & 0.348 \\
\hline $\mathrm{b}_{\mathrm{R} 4}$ & -1.160 & 0.072 & $\mathrm{~b}_{\mathrm{R} 1}$ & -0.009 & 0.009 \\
\hline $\mathrm{b}_{\mathrm{A} 2}$ & 0.007 & 0.002 & $\mathrm{~b}_{\mathrm{R} 2}$ & 0.131 & 0.021 \\
\hline $\mathrm{b}_{\mathrm{A} 4}$ & 0.038 & 0.017 & $\mathrm{~b}_{\mathrm{R} 4}$ & -1.568 & 0.121 \\
\hline $\mathrm{b}_{\mathrm{A} 5}$ & 0.046 & 0.019 & $\mathrm{~b}_{\mathrm{A} 8}$ & -8936.000 & 2328.940 \\
\hline $\mathrm{b}_{\mathrm{A} 6}$ & -0.020 & 0.012 & $\mathrm{~b}_{\mathrm{A} 10}$ & -0.555 & 0.050 \\
\hline $\mathrm{b}_{\mathrm{A} 8}$ & -6157.000 & 1496.620 & & & \\
\hline $\mathrm{b}_{\mathrm{A} 9}$ & -0.001 & 0.000 & & & \\
\hline $\mathrm{b}_{\mathrm{A} 10}$ & -0.373 & 0.031 & & & \\
\hline
\end{tabular}

Estimated coefficients, $\mathrm{b}_{\mathrm{T} 1-1}, \mathrm{~b}_{\mathrm{T} 1-3}, \mathrm{~b}_{\mathrm{T} 1-5}, \mathrm{~b}_{\mathrm{T} 1-8}$ and $\mathrm{b}_{\mathrm{T1}-11}$, are statistically significant in many cases. There are some common features as follows. (1) When the probability of failure is low, the sign of estimated coefficients of degree of trust in TV news program and news study are negative. Oppositely, when the probability of failure is high, the sign of estimated coefficients of them are positive. That is, when degree of financial turmoil is low, individuals who trust in information sources such as TV news program and news study tend not to withdraw their deposits, but they tend to withdraw their deposits when degree of financial turmoil is high. (2) Because sign of estimated coefficients of degree of trust in 2-channel and e-mail or phone calls with friends are positive, individuals who trust in these information sources tend to withdraw their deposits. (3) When the probability of failure is low, the sign of estimated coefficient of the degree of trust in conversations of strangers is positive. Oppositely, when the probability is high, the estimated coefficient tends not to be statistically significant. That is, individuals who trust in conversation of strangers tend to withdraw their deposits when the probability is low. However, when the probability is higher than a constant level, the conversation of strangers does not affect to their withdrawal behavior.

Next, the estimated coefficients, $b_{T 2-5}, b_{T 2-7}, b_{T 2-8}$, $b_{T 2-9}$ and $b_{T 2-11}$, are not statistically significant in many cases. On the other hand, the other estimated coefficients $b_{\mathrm{T} 2-1}$ and $b_{\mathrm{T} 2-4}$ are statistically significant and the sign are negative in many cases. In the case that the probability of failure is low, sign of estimated coefficient, $b_{\mathrm{T} 2-3}$, is negative. The sign of others, $b_{\mathrm{T} 2-2}$ and $b_{\mathrm{T} 2-10}$, are positive. From these results, we find that degree of trust in information sources or frequency of accessing the sources does not uniformly affect withdrawal behavior and by features of the degree or the frequency the effects are different even if information source is the same.

About degree of friends or colleagues exchanging information, we find that the estimated coefficient, $b_{\mathrm{E} 2}$, is not statistically significant, but the estimated coefficient, $b_{\mathrm{E} 1}$, is statistically significant in many cases. Then, the sign of coefficient is negative when the probability of failure is low. On the other hand, it is positive when the probability is high. This result may not be robust, but is very interesting. From sign of estimated coefficient of both degree of trust in e-mails and conversation with friends or colleagues and rate of friends or colleagues bandying about failure of bank, we can explain the mechanism of bank run such as the case of Toyokawa shinkin and Saga bank in Japan.

About transactions of individuals with banks, we find that estimated coefficient, $b_{R 1}$, is not statistically significant in the case that the probability of failure is low, but the coefficient is statistically significant and the sign of it is negative if the probability is higher. Wes can interpret that for diversification of risks individuals tend to increase the number of bank accounts if financial turmoil is higher and by doing so they tend not to withdraw their deposits. In addition, the estimated coefficient, $b_{R 2}$, is statistically significant and the sign of it is positive in many cases. So, we find that the probability of withdrawing deposit is higher if total amount of deposit is higher.

About individuals' attributes, in many cases the estimated coefficients, $\mathrm{b}_{\mathrm{A} 1}, \mathrm{~b}_{\mathrm{A} 2}$ and $\mathrm{b}_{\mathrm{A} 4}$, are statistically significant and the sign of them are positive, respectively. These factors are related with withdrawal behavior. In some cases, the estimated coefficients, $\mathrm{b}_{\mathrm{A} 5}$ and $\mathrm{b}_{\mathrm{A} 6}$, are statistically significant and sign of the 
former is positive and the latter is negative. This means that individuals who have more annual income tend to withdraw their deposits, but individuals who have more debt tend not to withdraw their deposits.

We find that the coefficient, $b_{A 8}$, is statistically significant and the sign of it is negative in the case that the probability of failure is higher. This result implies that risk-averse individuals tend not to withdraw their deposits when financial turmoil is higher.

In many cases, the estimated coefficient, $\mathrm{b}_{\mathrm{A} 9}$, is statistically significant and sign of it is negative. This means that individual expects economic growth rate in the future 10 years is higher tends not to withdraw their deposits. On the other hand, in some cases, the estimated coefficient, $\mathrm{b}_{\mathrm{A} 10}$, is statistically significant and sign of it is negative. This means that individuals who trust in government tend not to withdraw their deposits. This result is very interesting, too.

\section{CONCLUSION}

We refine the model in Takemura and Kozu (2009) and investigated the relationships between individual's deposit withdrawal behavior, economic factors and psychological factors using micro data from a Webbased survey. As a result, it is found that some relationships between individual's deposit withdrawal behavior and economic and psychological factors. In this study, sign of estimated coefficients of economic factors are consistent with one of economic theory in many cases. In addition, we find that degree of trust in information sources or frequency of accessing the sources does not uniformly affect withdrawal behavior and by features of the degree or the frequency the effects are different even if information source is the same and that individual who is risk averse and/or trust in government tends not to withdraw their deposits. This result is very interesting. As well as Takemura and Kozu (2009), we find that individual tends not to withdraw his deposit if individual correctly understands the Japanese deposit insurance scheme. Since ratio of individuals who do not correctly understand the Japanese deposit insurance scheme is around 55\% now, we should reduce the ratio. For reducing the ratio, based on this result, we propose that government should announce and educate the scheme to people strongly.

\section{ACKNOWLEDGEMENT}

This study was supported by "a Promotion Project for Joint Research between the Humanities and Social Science" from the Ministry of Education, Culture, Sports, Science and Technology, Japan (MEXT), 20082009 and "a Promotion Project for Distinctive Joint Research” from MEXT, 2010-.

\section{REFERENCES}

Allen, F. and D. Gale, 2007. Understanding Financial Crises. 1st Edn., Oxford University Press, USA., ISBN-10: 019925141X, pp: 320.

Ohtake, F., Y. Shiraishi and Y. Tsutsui, 2010, Happiness in Japan: Gaps, Labor and Family, Nippon Hyoronsya.1st Edn., Japan Society Reviews, Japan, ISBN-13: 9784535555983, pp: 296.

Shiller, R.J., 2008. The Subprime Solution: How Today's Global Financial Crisis Happened and What to do About It. 1st Edn., Princeton University Press, USA., ISBN-13: 9780691139296, pp: 196.

Takemura, T. and T. Kozu, 2009. An empirical analysis on individuals' deposit-withdrawal behavior's using data collected through a web-based survey. Eurasian J. Bus. Econ., 2: 27-41. http://www.ejbe.org/EJBE2009Vol02No04p27TA KEMURA-KOZU.pdf

Yada, K., T. Washio, Y. Ukai and H. Nagaoka, 2009. Modeling bank runs in financial crises. Rev. Socionetwork Strategies, 3: 19-31. DOI: 10.1007/s12626-008-0005-3 